\title{
Local Skills and Social Capital to Improve Creative Industry of Thematic Kampong
}

\author{
H S Rini \\ Sociology and Anthropology Department, \\ Faculty of Social Sciences, Universitas Negeri Semarang \\ \{hartatisulistyorini@mail.unnes.ac.id\}
}

\begin{abstract}
The purpose of this study was to analyze the significance of local skills and social capital in the growth and development of the people's creative industry that developed in the thematic kampong policy in Semarang and the challenges it faces. The methods is qualitative descriptive by using the comparison of the three thematic kampong in Semarang. The results shows that: 1) local skill was used for determining the characteristics of the people's creative industry; 2) the form of strengthening local skills are conducted by training in skills, teaching skills from generation to generation, and improving innovations; 3 ) the role of social capital are seen in the aspects of socio-economic networks, trust, and norms, both in terms of production and product sales (direct and online); and 4) the challenges appear as internal challenges and external challenges on a larger scale.
\end{abstract}

Keywords: Creative industry, Local skill, Social capital, Thematic kampong

\section{INTRODUCTION}

Thematic Kampong is a product of the Semarang government policy as one of the responses in poverty reduction program in 2016-2021. As a multi-dimensional problem, the phenomenon of poverty is a problem that gets a lot of attention. The poverty alleviation approach is divided into three main things [1], there are :1) promoting opportunity among the poor (who lack assets, access to markets, and work opportunities), to increase their income and allow them to escape from poverty in terms of consumption and income levels; 2) enhancing security, which is reducing their vulnerability and enabling the poor to cope with unfavorable situations (illness, poor weather, natural disasters, worsening market conditions, and public safety); 3) facilitating empowerment, which makes formal political administrative and informal social institutions work in favor of the poor, who have tended to be disadvantaged and discriminated. There are any other poverty alleviation perspective in the form of [2]: a), direct approaches to benefiting the poor (immediate impact and long term and sustaining impact); b), indirect impact programs (environmental improvements; economic improvements; social improvements) ; and c), ethical considerations.

Various methods of poverty alleviation have been carried out, such as: integrated urban poverty reduction programs both in aspects of their needs and government institutions involved in it [3], learning programs for citizens / poor groups to become empowered [4], and industrialization for poverty alleviation [5]. In Semarang, the implementation of this thematic kampong as an integration of poverty alleviation programs, strengthening local potential, 
improving physical facilities, as well as part of tourism development. This step is included in the Great Gate program (Joint Movement for Poverty Reduction and Unemployment through Economic Harmonization, Education, Ecosystems and the Community Ethos) / Gerbang Hebat (Gerakan Bersama Penanggulangan Kemiskinan dan Pengangguran melalui Harmonisasi Ekonomi, Edukasi, Ekosistem, dan Etos Bersama Masyarakat). The development of their own thematic kampong is based on distinctive character and local potential owned by each community, such as : pelangi kampong, batik kampong, cultural kampong, agro education kampong, jamu kampong and others.

Thematic kampong are a region living under the administration of the kelurahan (village) that shows identity / meaning of a potential community or region that is raised and highlighted on the results of mutual agreement [6]. This policy was also realized in the number of implementation of thematic kampong which increased from year to year. In 2016, as the first year launch, there were 32 kampongs that were categorized as pilot projects in the program. In 2017, there are 80 new thematic kampongs and in 2018 there will be an additional 65 villages. Thus in 2018, all 177 kampongs in Kota Semarang have been integrated into the thematic kampong program.

Thematic kampong is expected to become an icon of development in Semarang. Some mass media perpetuate the development through spread the news in the internet and social media. This era of industry 4.0 has become a tremendous carrying capacity for the spread of the local potential to all regions, both national and international. This is considered as a great expectation in developing regional area through locality-based. In addition, this program is also expected as a new force to revive the urban economic aspects, in form of the creative industry driven by skills possessed by the local community. Malang and Denpasar show creative industry, that are conducted by tourism activity and higher education attractiveness [7].

Based on it, the purpose of this study was to analyze the significance of local skills and social capital in the growth and development of the people's creative industry in the thematic kampong policy in Semarang and the challenges it faces. The research questions are : 1) Why the local skill is an important aspect in the thematic kampong development ;2) what is the form of strengthening local skills in the development of thematic kampong ; 3 ) how does the role of social capital in the development of people 's creative industries in the thematic kampong; and 4) how does the development of the creative industry in thematic kampong based on local skills and social capital. This research uses the social capital concept by Putnam [8], that underline the social capital into : social network, trust and norm as tool of analysis.

\section{RESEARCH METHOD}

This study uses a qualitative descriptive approach, which involves comparative studies in three thematic kampong in Semarang, there are : Malon natural kampong, Siroto traditional snack kampong, and the souvenir kampong of Tambakaji. Data is obtained by observation in each village; interview with related business actors and the local community; and documentation to get support for data reinforcement. Data validity is done by data triangulation, sources and methods. Data analysis using interactive models [9], that consist of : data collection, data reduction, data display, and conclusions drawing. 


\section{RESULT AND DISCUSSION}

\subsection{Three Thematic Kampongs in Semarang}

The characteristics of the three thematic kampongs are interested to explore related to the aspects of the products they develop, the business actors involved in, and the length of time they are developed. First, Malon natural kampong in Gunungpati which has developed as a thematic kampong since 2016. The main product of this kampong is commodity-based on Edu-tourism batik with natural dyes (both stamp and hand-painted batik). In the same time, visitors can buy products and take part in the training of batik making. While, the supporting products are food (krembis satay), drinks (wedang Malon), farms (dairy cows), arts (jathilan), and traditional games (egrang, gobak sodor). The actors involved were : Zie batik as a pioneer, the groups of batik crafters, women's groups, and the young man. Second, Siroto traditional snacks kampong in Pudakpayung has developed as a thematic village since 2016. The business actors in it are those who have skills to process traditional food, even some of them transmit these skills to family members for generations. Some types of traditional snacks are: dawet, various rice cakes, fried banana and so on. Third, Tambakaji souvenir kampong in Ngaliyan. The products are mainly from knitwear, that formed into wallets, key chains, bags etc. This souvenir is usually used in weddings or other events. The development has been carried out since 2018 in this kampong by involving individuals and groups of citizens in it.

\subsection{The Importance of Local skill as a Base of People's Creative Industry}

This three thematic kampong have the similarity. Each region has one kind of commodity that is relied upon as the basic capital for the establishment of thematic kampong. In addition, commodities developed in the area are determined by skills that have been mastered by the local community called local skills. So, even though the thematic kampong program is a kind of topdown policy, but the development is based on the bottom up principle that accommodates people skills to be a strength to improve the welfare of the community.

The significance of this local skill is related to several things. First, the local skill was used as a basis for determining the special characteristics of thematic kampong in Semarang. Government identified the local potential in each area, and it considers as the uniqueness of the thematic kampong. In general, there are several indicators are used to determine the development of thematic villages [6] : a). Social (poor area, having potential, community empowerment, etc.); b). Economy (local potential both human resources \& natural resources, productive community, featured products); c). Infrastructure (slums, arid, messy area, decreased carrying capacity). It becomes quite diverse of thematic village in Semarang. It also presents the local wealth of community skills become the assets of the region and in the same time has function as problem solving in the issue of inequality and poverty.

Second, local skill gives hope for the sustainable development principle. This is based on the fact that many poverty alleviation programs are considered only as projects and have ceased to develop along with the end of the program and government interference. Through thematic kampong program, it bring a new hope. When the program is completed, the community continues to carry out activities and develop their capacity to get out of the problem of poverty because it part of their daily life.

Third, local skill as basic of the creative industry development in Indonesia. It start with the definition of creative economy which people using their imagination and exploring the relationship between creativity and business and money [10]. It also mean : creativity, skill and talent with the potential for wealth and job creation through the exploitation of their intellectual 
property [11]. It all definition, in line with The National Blue Print of The Creative Economy Development 2009-2015 that creative industries are industries that origin from the use of creativity, skills and individual talents to create prosperity and employment through the creation and utilization of the individual's creative and creative power [12]. Thus, the main idea of creative industry is: creativity, skill, and talent as tools of prosperity.

Local skills possessed by citizens are accommodated and developed in such a way and expressed in the socio-economic ideas of the residents. The skills became the starting point for urban area development. These things do not stop being a personal business that tends to bring personal benefits, but it is further developed into a joint venture of the community that has a wider impact. For local people, their potential is considered normal. But in the context of creative industries, the skills as important capital to expand the field of work, increase income, and ultimately become a way to improve people's welfare.

\subsection{The Form of Strengthening Local Skills}

The form of strengthening skills is carried out by training in skills, teaching skills from generation to generation, and the innovations on it. In Malon natural kampong, training programs supports the process of strengthening local skills, both in main skills and supporting skills. The main skills are emphasized in batik training, while supporting skills are in art training, local culinary and art performance. Batik training that conducted by Zie batik owners and the government, addressed to local residents who interested in learning batik skills.

In Siroto traditional snacks kampong, strengthening local skills is carried out with patterns derived between generations and daily routine production. There are at least 30 people involved in this household creative industry, with various products and are relatively different from each other. This variations both in product and skill are obtained from parents and families. Based on their experiences, the cooking skill will be more refined and improved in quality with direct production practices every day, rather than training programs from the government which sometimes do not match with their interests.

The tendency of strengthening local skills in Tambakaji souvenir kampong bears a resemblance to Malon's natural kampong, which is a pattern of socialization of those who master these skills to other people around them. However, the training did not involve other parties, such as government interference. The trainings are voluntary and free of charge.

Beside of their difference patterns of strengthening local skill, the similarities still occurred. Firstly, the involvement of community leaders who are considered as pioneers or people who mastered in local skills. They are actually important figures who voluntarily share their knowledge with the community so that the process of strengthening local skills can be more distributed and strengthen the identity of the thematic kampong. Secondly, strengthening infrastructure as a supporting tool that strengthens the presence of thematic kampong. This bring physical transformation and environmental arrangements that are considered to support the existence of thematic villages as urban community-based tourism. Malon natural kampong provides : batik tools (both for stamp and handwritten batik), the hall equipped with traditional music instruments, installation of Wi-Fi, and homestays. The facilities in Siroto traditional snacks kampong are : 1) entrance gate, 2) signatory on every house that runs a traditional snack business (approximately 40 pieces), which contains information about the owner of the business, address, telephone number, and type of traditional snacks; and 3). the existence of a marketing / store space that is used collectively. In the Tambakaji souvenir village, which is still newly inaugurated as a thematic kampong in 2018, strengthening of infrastructure facilities revolves 
around general environmental management with the construction of gates and environmental cleanliness.

\subsection{The Role of Social Capital in the Development of People's Creative Industries}

Putnam's perspective on social capital has become an analytical tool to see the development of creative industries in the thematic village of Semarang. He stated that social capital refers to connections among individuals - social networks and the norms of reciprocity and trustworthiness that arise from them [13]. These three basic can be discovered in the stages of :a) growing and strengthening local skills; b) production; and c) product sales.

As the first aspect, social networks can be found in a whole series of processes that occur in the creative process. At the stage of growing and strengthening local skills, there are two basic things, : 1) the transfer of knowledge as the basis for the formation of local skills, from people who become pioneers (have skills) to the surrounding residents; and 2) the strengthening process guided by the pioneers themselves or in collaboration with other parties such as government, campus, CSR etc. In the production stage, there are some interesting findings : 1) pioneers involve local people to join in the production process when the demand is booming; 2) pioneers invited local people who have high ability to work together to increasing the skill, in purpose of transmit their knowledge to others; 3) the differentiation of product was to minimize conflicts between business actors themselves; and 4) cooperation to the materials and equipment providers to reduce production costs. In the sales stage, there are several interesting phenomena : 1) networks system was built from the meeting of producers and consumers in the direct sales; 2) direct sales network using collective facilities (such as education tourism packages and shared shops / showrooms); 3) braided network with the institutions as customers; 4) promos and publications via the internet with a web page connected to the government web; and 5) the use of online shops and social media that are proven to increase product demand and expand networks.

The interesting finding of socio-economic network is in the use of technology for the products promotion expansion. Nowadays, the industrial revolution 4.0 puts social media, online shops, and the internet as an inseparable part of people activities, especially in the context of developing this creative industry. The network of these machines that are digitally connected with one another and create and share information that results in the true power of Industry 4.0 [14]. The significance of industry 4.0 is inevitable, because: 1) touching our lives every day; 2) integrating the digital and physical world (real); 3 ) not only about production manufacturing chains, but also about managing business, revenue growth, and even influencing the community [15]. The consequences is people must strengthen their resources and skills to synergizes with information technology. Many experts suggest that the fourth industrial revolution will benefit the rich much more than the poor, especially as low-skill, low-wage jobs disappear in favour of automation [16]. Fields of work that are routine, without specific skills, and minimal innovation, will be eroded by the era and easily replaced by machines. The vulnerable groups in such situations is people whose resources are very limited or poor. Therefore this creative industry which is based on the innovation of the local skills of the community becomes a policy that is integrated with the urban poverty alleviation program. The next aspect is trust. The principle of trust in society is formed by not compete to do production process by taking others specialization, even though the opportunity is very open to do so. It is an effort to minimize competition and conflict of interest which in turn destroys social ties among the people themselves.

Finally, the aspects of social norms is a guidelines for living together in this creative industry. The agreed norms or rules arise from the formation of business groups. It regulate the 
principles of production and product sales based on the principle of cooperation. In batik kampong, it is highlighted through: 1) the batik's differentiation price between large and small business group; and 2) an education tourism package that combines batik with other local commodities such as culinary and arts performance. In traditional snack kampong, the norm origin from food diversity products but with the same packaging to avoid gaps. In a souvenir kampong, the sustainability of this business is based on the principle of mutually reinforcing capacity and involving people's collectivity.

With the involvement of social capital aspects in the process of developing creative industries, this principle reinforces that social capital affects the productivity of actors (individuals and groups) and it poses characteristics of public goods [17]. What was built and worked through teamwork in each of the thematic villages shows that social capital has an important role to play in strengthening and developing existing achievements. The main approach to social capital is trying to create bonds, bridges, and linkages [18] among the people themselves with institutions outside.

\subsection{The Challenges}

In this study, the challenge is divided into : internal challenges and external challenges. Internal challenges involve various things that occur in the management, strengthening and development of thematic kampong itself. While the external challenge concerns the thematic kampong related to various parties in more complex relationships. The first internal challenge was found in the context of human capabilities to develop skills. It describes the limited methods for skill enhancement and product innovation. In fact, sometimes there are trainings that not match with the needs of skill development. The second is about the conflicts of interest among people. In the case of established thematic kampong, the conflict of interest develops in the issue of : who is the most meritorious party, who is the most benefited, and the lack of aspects of welfare distribution for the community.

In the other hand, the external challenges come from the situation outside the kampong. This is broader and more complex problems, which dealing with the government policies and the future of thematic kampong. People needs fund, but the budget from government can be used to strengthen the public infrastructure only. For the future of thematic kampong development, studies and evaluations have been carried out. The community is still waiting, what policy pattern will be applied to solve the problem and to develop thematic kampong, in case will be adaptive to the changes and dynamics in society. It is based on the change of creative products and industries are initiated by demand, technology, policy, and globalization [19] [20].

\section{CONCLUSIONS}

The skills possessed by the local community (local skills) become an important aspect in the development of urban creative industry in thematic kampong. The use of social capital through various efforts and the achievements need to be appreciated and critized. Through this program, the urban socio-economic aspect began to appear, but there are still some challenges that must be resolved immediately. Moreover, the implementation of this program is a unique pattern that synergizes physical development, strengthens urban capacity and capability to improve welfare and reduce poverty. 


\section{REFERENCES}

[1] T. Yanagihara, "Approach to Poverty Reduction in Developing Countries and Japan's Contribution," Technol. Dev., vol. 17, no. 16, pp. 10-14, 2003.

[2] A. L. Ferriss, "Approaches to reducing poverty," Appl. Res. Qual. Life, vol. 1, no. 3-4, pp. 217-226, 2006.

[3] E. Setijaningrum, "Program terpadu penanggulangan kemiskinan di Kota Surabaya Integrated program design to overcome poverty in Surabaya," Masyarakat, Kebud. dan Polit., vol. 30, no. 8, pp. 13-19, 2017.

[4] A. Taufiq, D. Erowati, and Wijayanto, "UPAYA PENANGGULANGAN KEMISKINAN BERBASIS PEMBERDAYAAN MASYARAKAT LOKAL (Belajar dari Pelaksanaan Program Penanggulangan Kemiskinan Perkotaan di Kelurahan Bintoro, Kecamatan Demak, Kabupaten Demak," Polit. J. Ilmu Polit., vol. 1, no. 1, pp. 134-158, 2013.

[5] S. A. Alvarez, J. B. Barney, and A. M. B. Newman, "The poverty problem and the industrialization solution," Asia Pacific J. Manag., vol. 32, no. 1, pp. 23-37, 2015.

[6] B. K. Semarang, "Penanggulangan Kemiskinan Kota Semarang," Semarang, 2017.

[7] A. Hidayat and A. Asmara, "Creative industry in supporting economy growth in Indonesia: Perspective of regional innovation system Creative industry in supporting economy growth in Indonesia : Perspective of regional innovation system," in IOP Conf. Series: Earth and Environmental Science, 3rd International Conference of Planning in the Era of Uncertainty, 2017, pp. 1-10.

[8] R. D. Putnam and K. A. Gross, "Introduction," in Democracies in Flux : The Evolution of Social Capital in Contemporary Society, R. D. Putnam, Ed. New York: Oxford University Press, 2002, pp. 1-19.

[9] M. B. Miles and A. M. Huberman, "Qualitative Data Analysis.” Jakarta: UI press, 1992.

[10] J. Howkins, The Creative Economy: How People Make Money from Ideas. Penguin, Uk, 2013.

[11] PRG, "The Creative Economy: Key Concepts and Literature Review Highlights," 2013.

[12] bekraf.go.id, "Apa itu Ekonomi Kreatif." .

[13] L. Andriani, "Social Capital: a Road Map of Theoretical Frameworks and Empirical Limitations," London, 2013.

[14] B. Marr, "What is Industry 4.0? Here's A Super Easy Explanation For Anyone," Forbes, 2018.

[15] M. M. Cotteleer and B. Sniderman, "Forces of change: Industry 4.0," 2017.

[16] B. Marr, "Why Everyone Must Get Ready For The 4th Industrial Revolution," Forbes, 2016.

[17] H. Bhandari and K. Yasunobu, "What is Social Capital? A Comprehensive Review of the Concept,” Asian J. Soc. Sci., vol. 37, no. 3, pp. 480-510, 2009.

[18] M. T. Hyyppä, What Is Social Capital? 2010.

[19] C. Jones, M. Lorenzen, and J. Sapsed, The Oxford Handbook of Creative Industries. Oxford: Oxford University Press, 2015.

[20] K. Saddhono, S. T, Widodo, M. T. Al Makmun, and M. Tozu, "The study of philosophical meaning of batik and kimono motifs to foster collaborative creative industry." Asian Soc. Sci. vol. 10 no. 9 pp 52-61, 2014 